\title{
Geo-Economic Priorities of Russian Federation and Federal Republic of Germany in the Context of Overcoming the Crisis
}

\author{
Nikita D. Khoroshun ${ }^{1}$ \\ ${ }^{1}$ Russian University of Economics Plekhanov, Russian Federation \\ Correspondence: Nikita D. Khoroshun, Neopalimovskiy s-str 1-st, 8-8, Moscow, 117997, Russian Federation. \\ E-mail: nkhoroshun@gmail.com
}

Received: June 23, 2014 Accepted: July 18, 2014 Online Published: September 28, 2014

doi:10.5539/ass.v10n20p184 URL: http://dx.doi.org/10.5539/ass.v10n20p184

\begin{abstract}
The author of this article reveals the essence of the "geo-economics" concept and investigates specific methods of economic policy, Economy, used in the applied geo-economics. During the whole post-Soviet period, Russia and Germany continue to be the major economic partners. The author notes that currently Germany is forming as a new form of geo-economic power within the international relations, demonstrating a reluctance to use military force as an instrument of foreign policy, even in a multilateral context. It is revealed that the global financial and economic crisis had a negative impact on investment cooperation between the two countries: for example, the volume of FDI from Germany to Russia decreased by 30.1\%, from Russia to Germany-by nearly a half (48.4\%). At the same time, the lowest point in FDI volumes was passed in 2011, and the growth has been renewed since the year 2012. The author concludes that, despite the general decline in investment activity on the background of the ongoing global financial crisis, Germany is still one of the largest investor countries of Russia. German-Russian trade and economic cooperation is aimed at building sustainable economic development capable of ensuring the growth of key indicators in the post-crisis period. Strategic partnership stimulates translational processes in the economy of both countries. The success of the bilateral cooperation between Russia and Germany in the international economy shows positive dynamics of foreign trade, FDI growth, etc. However, in 2013, it is noticed a decrease in the rate of development of bilateral economic relations between Russia and Germany.

The new qualitative feature of the cooperation dynamics is seen by the author in the involving of the innovation sphere that is a link between science and industry, in the field of bilateral cooperation. Discussed in this article priorities give only some of the possibilities for the future cooperation development between Russia and Germany in five major segments of the economy: energy, engineering, aviation, transport, and pharmaceuticals.
\end{abstract}

Keywords: geo-economics, geopolitics, geotechnologies, cooperation partnership

\section{Introduction}

The current stage of the world economy development is characterized by growth and development of the developing countries' economies, which include Russia as well. This means that there is taking place a strong geo-economic structural shift that has already had an impact on the focus of global economic growth, and will continue to have geopolitical consequences associated with political risks and opportunities for economic development.

In the present conditions of the globalization development stage associated with overcoming the consequences of the global financial crisis, a special urgency to develop the strategy and tactics of public policy acquires a geo-economic approach.

Currently, the development of national economies is impossible without interaction with the world economic systems. Huge perspectives are put into the development of cooperation between Russia and Germany. Therefore, the development of specific measures on intensifying economic and political cooperation between these states is of particular relevance.

\section{Methods}

Despite the fairly widespread use of the term "geo-economics", there is currently no generally accepted definition of this concept. Sanjaya Baru, a head of the program on geo-economics and strategy of the 
International Institute for Strategic Studies (IISS) says that geo-economics can be defined in two ways (Sanjaya, 2012):

As the economic consequences of geopolitical trends and projection of national authority ("trade follows the flag");

Geopolitical consequences of economic phenomena ("flag follows the trade"), which are the subject of geo-economics.

Geopolitics and geo-economics complement each other, but are not complete. The third approach is the geotechnologies. It is necessary to understand the specific technological innovation, which, thanks to rapid commercialization and geo-economic benefits, and which, through the strategic deployment and potential militarization, will have important geopolitical influence. Therefore, when analyzing the global dynamics and the changes, it is essential to take all three approaches and consider complicated causal relationships between them.

The "geopolitics" discipline goes back to the work of European scientists and diplomats of the nineteenth century, whose main task was the territorial control and the ability to build up forces abroad. Geopolitical power factors include population, natural resources, armed forces, usual and nuclear weapons. These factors remained the dominant approach to the comparative analysis of forces during the main part of the twentieth century (Parag, 2012).

In the 1990s, the term "geo-economics" gained the notoriety as a counterweight geopolitical approach. Unlike geopolitics, geo-economics emphasizes the basis of trade. From this point of view, the size of the gross domestic product (GDP) and trade balances growth, foreign exchange reserves and foreign investments are critical factors in the assessment of the real balance of power between the states.

Effectiveness of geo-economics as a policy is a condition for the survival of the state and also involves among other things the ability of the country to adapt to the current situation in the world market. Therefore, the applied geo-economics uses not only the traditional methods of economic policy, but also special methods, which are combined into two main groups (Chernaya, 2012):

Colbertism of high technologies;

\section{Methods of Economic Warfare.}

The first group of methods is focused on the growth of domestic state competitiveness based on the innovative solutions through structural measures, as well as through investments in human resources with a view to guaranteeing its own population an employment with the highest added value. The measures include structural and institutional mechanisms for geo-economic exploration, infrastructure development, tax policy and innovation.

"Colbertism of high technologies" methods are very similar to the military concept of "preparing the nation for war," assuming the mobilization of internal forces and resources by both direct and indirect ways. For receiving the competitive advantages by the country there should be considered the interests of all geo-economic entities, including the unaffected by influence, for example, of transnational forces. Their internal mechanisms must be considered not only because they may pose a threat to any solutions, but also because they possess the ability to open a lot of opportunities that need to be addressed for the benefit of the State.

"Colbertism of high technologies" methods are closely related to the geo-economic competition, aimed at training national leaders and internationalization of businesses.

Methods of geo-economic competition are implemented within the two main types of strategies-defensive and offensive.

Defensive strategy is being implemented by the methods of "educational protectionism", which were set out in detail and described by the German economist Friedrich List. The scientist pointed to the important role of protectionism in the development of the productive forces of the nation, emerging from the development of industry, agriculture, education, culture, science and public institutions; emphasized the role of these institutions in the development of the welfare of all the individual members of society (Panyshyn, 2014).

Offensive strategy is carried out by methods of "effective protection", which is expressed in support of national industries, which formation and adaptation in the conditions of highly developed international structures requires some time. 
The second group of methods includes the methods of geo-economic war involving enemy endamagement by the nonmilitary economic means, as a result of which there is a redistribution of national and global income in favor of the winner.

Among the geo-economic war methods there is used a large share of the national capital in foreign investments, a share of owned products within the import of competitors, rate pegging in national currencies to the currencies of the affecting state, control over a considerable amount of external debt, etc.

The main ways of geo-economic war waging include, for example, the non-tariff barriers. Dissemination of non-tariff barriers is caused by the fact that their administration is the government's privilege, and they are not regulated by international agreements. Governments are free to apply any non-tariff barriers, which is impossible with respect to tariffs, which are regulated by the WTO. In addition, non-tariff barriers are not usually lead to an immediate increase in the price of goods and so the user does not feel their effects in the form of additional tax (administered tariff commodity price increases in the amount of duty) (Kozak et al., 2013). In some cases, the use of non-tariff methods in the relatively liberal customs regime may lead to more restrictive state trade policy in general.

Non-tariff barriers can be classified into the following groups:

Quantitative (quotas, licensing, "voluntary" export restraints);

Hidden (technical barriers, internal taxes and fees, government procurement, the requirements for the local component content);

Financial (dumping, subsidies, export crediting).

The choice of method depends on the development paradigm that underlies the national foreign trade policy and the chosen strategy to increase the export potential of the national economy.

One of the most resonant geopolitical concepts reflecting a clear picture of international relations and methods of forecasting the future strategic alignment of forces in the world is a civilizational model by Huntington S.F. In his historical and philosophical treatise "The Clash of Civilizations and the Remaking of World Order", published in 1996 (Huntington, 1996), Huntington actually suggested what he called "the Japanese strategy of maximizing economic power" and identified five sources of such force:

a) Manufacturer's domination, which is a choice in favor of economic power over welfare;

b) Industrial orientation, which is a creation of industrial capacity for both domestic and export markets, with a focus on strategic, high-tech products with high added value;

c) Market share prevails over the profit, which is a deliberate strategy to invest in loss-making enterprises for the sake of final industry domination;

d) Import restrictions, which are establishing limits on imports and foreign direct investment inflows;

e) Steady surplus, which is a creation of currency reserves through sustained positive trade balance and intervention in foreign exchange markets with the purpose of maintaining a strong currency.

\section{Results}

Collapse of the Soviet Union was the most important geo-economic phenomenon in the postwar period. Long before the Soviet Union collapsed in fact, its Russian economy began to falter. Few analysts could predict the collapse of the Soviet Union and even in the late 1987, Kennedy, summing up his analysis of the paradox of Soviet economic decline and military construction, noted that "it did not mean that the Soviet Union was close to collapse, it should be seen as a country of almost "supernatural force". This means that the USSR faces with an uncomfortable choice.... Consequently, efforts and calls for improvement of the Russian economy will grow stronger. But since it is unlikely that the Soviet regime refuses from the "scientific socialism" in order to stimulate the economy or to dramatically reduce the burden of defense expenditures and thereby affect the military foundation of the Soviet state, the prospects of escaping from the contradictions that confront the USSR are not considered to be good" (Kennedy, 1987).

The report by Cecchini P., which initiated the project of creating a single economic and monetary union in Europe (Cecchini, 1988), was made against the background of growing competitiveness in Japan and the European fear of losing global market share of Japanese and American companies. Interestingly, that despite its growth as a major power with the second largest economy in the world, Japan has not become a "geo-economic nation" after failing to convert its new economic influence in the military and political power. 
The reunification of Germany is also a consequence of the Cold War. It involved the geo-economic consequences in terms of enlargement of the European Union (EU), and an even greater surge of economic and monetary integration within the EU. Emphasis was placed on geo-economic and geopolitical role of the EU in the international affairs.

This contrasts with what is happening now, during the financial crisis in Europe, when Germany is increasing its geopolitical space. Currently, Germany is formed as a new form of geo-economic power within the international relations, demonstrating a reluctance to use military force as an instrument of foreign policy, even in the multilateral context.

Currently, the German economy is the largest and also, as it was shown by the financial crisis of 2008-2009, the most stable and competitive economy in Europe.

GDP growth, that began after the crisis in 2010 and continued in 2011-2012, still preserved in 2013, amounting to $0.4 \%$. At current prices, the GDP growth amounted to $2.67 \%$ (2.74 trillion of Euros in 2013 against 2.66 trillion of Euros in 2012) (Kennedy, 1987). Inflation and unemployment remained at an acceptable level-in fact; they were even slightly lower than in 2012.

The principal economic development indices of Germany for the period 2009-2013 are presented in Table 1.

Table 1. The principal economic development indices of Germany for the period 2009-2013 (German Council of Economic Experts, 2013)

\begin{tabular}{llllll}
\hline Index & 2009 & 2010 & 2011 & 2012 & 2013 \\
\hline Real GDP,\% to the previous year & -5.1 & 4.2 & 3.3 & 0.7 & 0.4 \\
People engaged into economy, in thousands of people. & 40370 & 40603 & 41164 & 41608 & 41860 \\
Unemployment rate, \% & 8.1 & 7.7 & 7.1 & 6.8 & 6.9 \\
Budget surplus, billions of Euro & -73.0 & -103.6 & -19.7 & 4.2 & 1.3 \\
Budget surplus to the nominal GDP, \% & -3.1 & -4.1 & -0.8 & 0.1 & 0.1 \\
\hline
\end{tabular}

In 2013, there continued the process of state budget consolidation-for the second consecutive year, the German government was able to draw it up with the minimal surplus. This time, it was again positive-its share of GDP was about $0.1 \%$, which was fully in line with the government's goal not to exceed the limits of the structural budget deficit in the amount of $-0.5 \%$.

The share of industry in the German economy, with their typical medium-sized businesses is $22 \%$ and allows it to occupy a leading position in the market. In the other major industrial countries in Europe (France, Italy, UK) recently occurred powerful processes of de-industrialization, and therefore their share in this sector is much less.

Germany has the greatest competitive advantage in almost all major industries, including automotive, aviation, electrical engineering and production of medical equipment, special equipment and vehicles, chemical and pharmaceutical industries, machine tools, agricultural machinery manufacturing, food processing equipment, engines and drives, apparatus and measuring instruments.

In 2013, the total foreign trade turnover for the first time since 2009 fell by $0.2 \%$, amounting to 1.989 trillion euros-export involved 1.094 trillion Euros, import-0.895 trillion Euros (Russland 2013, 2013). Export quotas of most corporations included into stock indices reach an average of 50\% and more (Adidas, Bayer, Daimler, etc.). Medium business firms and so-called «hidden champions», highly specialized companies with a focused portfolio, very often come to the level of $80 \%$ of exports at the expense of successful niche products.

The share of gross investment in GDP in Germany decreased from 21.5\% in 2000 to $17.6 \%$ in 2012. During the same period in the Eurozone (within the year 2000) without Federal Republic of Germany it was steadily growing until 2008, and in generally was higher than the German investment quota. If Germany had the $14^{\text {th }}$ quota (as in the Eurozone), the additional investments in its economy in the determined period amounted to 831 billion Euros, i.e. an average of about 64 billion per year (about $2.4 \%$ of GDP).

Economic dominance in Europe is largely based on the stability of the monetary and exchange rate systems. Already relatively well-established practice is to place the debt at negative interest. Thus, in 2011 Germany held 70 public debt placements, and for 21 of them the rate was negative. Large investors are trying to find the most reliable facilities for investment. In particular, many foreign pension funds under the laws of their countries are obliged to invest some funds in the bonds of only those states that possess the highest reliability rating. Taking 
into account France's loss in 2012 of the highest investment rating AAA in compliance with the Moody's agency classification, the government bond market, satisfying the requirements of investors, declined sharply. In fact, investors receive reliability, but suffer losses. According to experts, this helps Germany, on the one hand to attract more investments, which is advantageous for it, and on the other to borrow money on the international market in the long term perspectives, which constitutes threat for the currency union, because it reduces access to financing by other countries.

Over the past decades in Germany there was completed the process of transformation of the R \& D system into the national innovation system. The main difference of the modern German NIS is that unlike the U.S. and Scandinavian countries, where the preference is given to the selective measures (focused approach) and targeted investments in the R \& D (mission-oriented), in Germany there is widely used a so-called holistic approach (holistic approach), which is to use a broad portfolio of innovative measures to support innovational economic renewal.

Since the late 1990s of the XX century, the German eastern policy has been oriented on the strategic cooperation with Russian Federation and also tacitly implied the involvement of countries of the Central and Eastern Europe into the orbit of European integration.

FRG builds economic cooperation with Russia in line with the EU policy. As an active member of the EU and other integration structures of the West, it largely determines their policy towards Russia. However, bilateral cooperation has not lost its significance and, despite difficulties acquires features of a strategic partnership on an ever wider field of international cooperation (Russian-German economic cooperation, 2013).

Currently, Germany is one of Russia's main partners in Europe. Trade and economic cooperation is carried out within a bilateral cooperation: in both directions there is provided import and export of goods, imports and exports of direct and portfolio investments, financial and credit resources, various types of services, as well as the transfer of new technologies, know-how, etc. In addition, there has been successfully developing cooperation in the spheres of immaterial production: cultural, tourism, science and technology and other industries.

By the end of 2013 the trade turnover between the two countries amounted to 76.52 billion Dollars (Statistics of the Russian-German trade cooperation, 2013), unlike the previous after crisis years, the 2013 was a year of not so much dynamic, how restrained development of bilateral economic relations. Unfortunately, there were not justified the forecasts for further foreign trade turnover growth, amounting in 2012 about 80.87 billion euros.

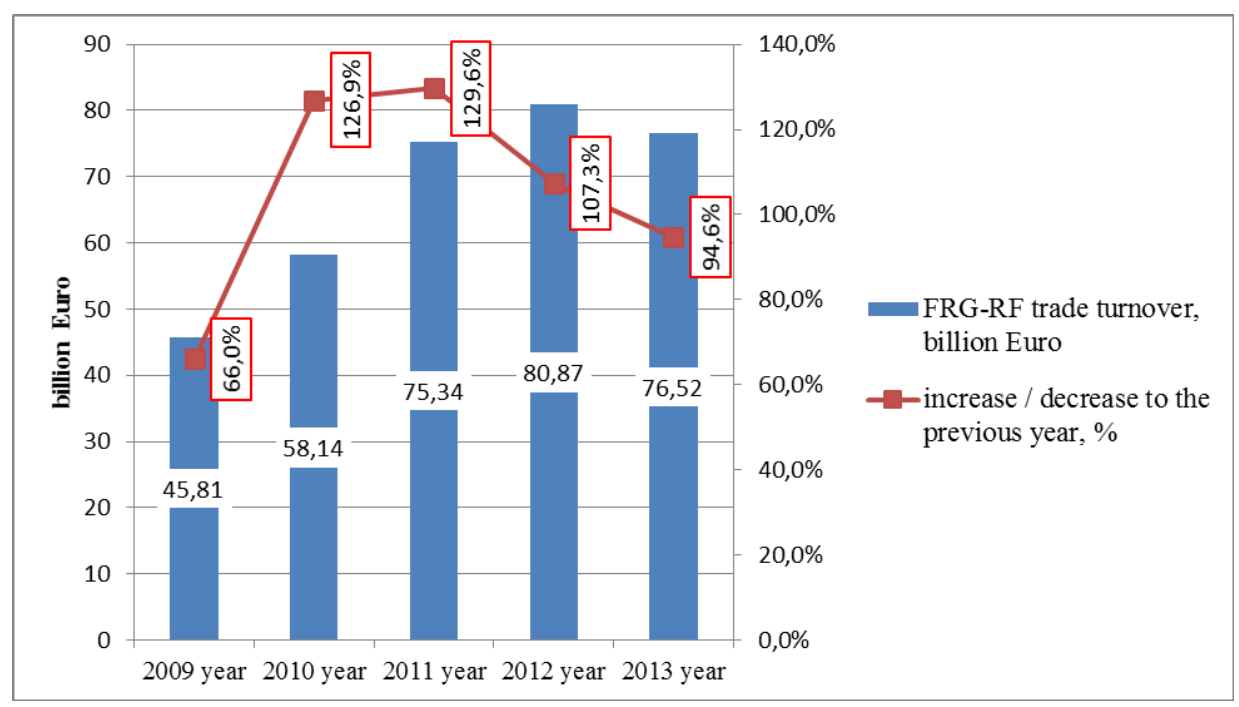

Figure 1. Dynamics of Russian-FRG trade turnover in 2009-2013

FRG-Russian trade turnover decreased by $5.4 \%$ in 2013, including: German exports to Russia-36.1 billion Euro (5.2\% down), while imports from Russia to Germany- 40.4 billion Euro (5.5\% down). Negative surplus for Germany was formed in the amount of 4.3 billion Euro, $7.5 \%$ down.

The main reason for the fall of trade performance in 2013 was as a strong reduction in exports to Russia and imports from Russia, it took place in March, October and December. 
Share of Russia in foreign trade turnover in Germany is 3.8\%, including FRG exports-3.3\% and FRG imports- $4.5 \%$ (in $2012-4.0 \%$ of turnover, including $3.5 \%$ of exports and $4.7 \%$ of imports).

According to the volume of trade turnover Russia occupies the 11th place among the leading trading partners of Germany-after France, the Netherlands, China, USA, UK, Italy, Austria, Switzerland, Belgium, and Poland (in 2012 Russia was on the 10th place, ahead of Poland).

With regard to the imports to FRG, Russia is on the 7th place-after the Netherlands, China, France, USA, Italy, and Great Britain (in 2012 Russia was on the same 7th place, after these same six countries).

With regard to the exports from FRG, Russia occupies the 11th place-after France, USA, UK, Netherlands, China, Austria, Italy, Switzerland, Poland, and Belgium (in 2012 Russia was on the same 11th place after these same ten countries).

In 2013 the major share of indices of the German-Russian trade in goods in the context of the six groups of industries is played by the energy engineering-its share of the total FRG-Russia turnover is $46.1 \%$ (Table 2).

Table 2. The trade turnover structure of FRG-RF in 2012-2013

\begin{tabular}{lllll}
\hline \multirow{2}{*}{ Industries } & \multicolumn{3}{l}{ FRG-RF trade turnover } \\
& 2012 & 2013 & Spec. gravity, 2013 & Changes \\
& million & Euro & $\%$ & \\
\hline Agriculture & 230 & 223 & 0.3 & 96.9 \\
Materials, raw materials and semi-processed materials & 13992 & 12983 & 17 & 92,8 \\
Investment goods & 21776 & 20401 & 26.7 & 93.7 \\
Consumer goods & 6876 & 6848 & 8.9 & 99.6 \\
Energy engineering & 36954 & 35256 & 46.1 & 95.4 \\
Not allocated to the groups of material production industries & 1040 & 813 & 1.1 & 78.2 \\
\hline
\end{tabular}

In the structure of the goods imported from RF to FRG, energy industries production amounts to $86.7 \%$, and also forms the cumulative deficit.

Hierarchy of other industry groups is as follows:

1) Industries of investment goods, occupying the second place in terms of turnover (26.7\%) and first places in terms of exports (55.6\%) and the cumulative surplus $(64.8 \%)$;

2) Industries of materials, raw materials and semi-processed materials are at the third places in terms of turnover $(17.0 \%)$ and the cumulative surplus (13.5\%), and on the second places in terms of exports $(23.7 \%)$ and imports (11.0\%);

3) Industries of consumer goods accounting for $8.9 \%$ of turnover, $18.1 \%$ of exports and $20.5 \%$ of the total surplus.

Agriculture and the goods not allocated to the groups of material production industries have no significant value.

In 2013 there was a decrease of deliveries of Russian goods, including the main raw material groups (Table 3).

At the same time declined the pace of imports of the German machinery and equipment.

Table 3. The goods import structure from RF to FRG in 2012-2013

\begin{tabular}{lllll}
\hline \multirow{2}{*}{ Industries } & \multicolumn{4}{l}{ Goods import from RF to FRG } \\
& $\begin{array}{l}2012 \\
\text { million Euro }\end{array}$ & $\begin{array}{l}\text { Spec. gravity, 2013 } \\
\text { Changes }\end{array}$ & Chan \\
\hline Agriculture & 86 & 81 & 0.2 & 94.6 \\
Materials, raw materials and semi-processed materials & 5028 & 4429 & 11 & 88.1 \\
Investment goods & 328 & 311 & 0.8 & 94.8 \\
Consumer goods & 322 & 296 & 0.7 & 91.8 \\
Energy engineering & 36665 & 35049 & 86.7 & 95.6 \\
Not allocated to the groups of material production industries & 335 & 252 & 0.6 & 75.3 \\
\hline
\end{tabular}


Sectorial structure of the German-Russian goods trading in goods in 2013 on exports from FRG to RF focused on the production of the three sectors, namely, mechanical engineering (in 2013 exports amounted to 8.1 billion Euros), automotive (7.6 billion Euros) and chemical industry (3.2 billion Euros).

Sources of the major impulses for the development of German-Russian trade in 2013 are shown in Table 4.

Table 4. Sources of the major impulses for the development of German-Russian trade in 2013

\begin{tabular}{lllll}
\hline $\begin{array}{l}\text { Positive impulses } \\
\text { Export from Germany }\end{array}$ & Import to Germany & & $\begin{array}{l}\text { Negative impulses } \\
\text { Export from Germany }\end{array}$ & Import to Germany \\
\hline $\begin{array}{l}\text { production of other means of } \\
\text { transport (+492 million Euros) } \\
\text { pharmaceutical industry (+259 } \\
\text { million Euros) }\end{array}$ & $\begin{array}{l}\text { coke chemistry and } \\
\text { petroleum refining } \\
\text { million Euros) }\end{array}$ & $\begin{array}{l}\text { automobile production } \\
(-1186 \text { million Euros })\end{array}$ & $\begin{array}{l}\text { oil/gas } \\
(-2808\end{array}$ & $\begin{array}{r}\text { extraction } \\
\text { Euros })\end{array}$ \\
\hline
\end{tabular}

Cooperation between Germany and Russia is developing not only in the area of foreign trade, but also in the field of investment. In the recent years Germany has strengthened its role of leading foreign investors in the territory of Russia. Despite the overall drop in investment activity on the background of the ongoing global financial crisis, Germany is still one of the largest investor countries, giving place only to Cyprus, the Netherlands and Luxembourg.

At the end of 2013 the total amount of accumulated in Russia German investments amounted to 21.3 billion U.S. dollars (in 2012-24.9 billion U.S. dollars), including direct investments totaling 12.7 billion U.S. dollars (in 2012-11.39 billion U.S. dollars), other financial investments-13.5 billion U.S. dollars (in 2012-17.5 billion U.S. dollars).

Russia occupies the $16^{\text {th }}$ place among the countries of German capital application, including the third place in the group of countries with the emerging markets (after China, located on the seventh place, and Brazil, which occupies the $13^{\text {th }}$ place), Russia falls behind China at almost $50 \%$, from Brazil-20\%. Among the countries, channeling their investments into Germany, Russia is on the $17^{\text {th }}$ place, including the second place in the group of countries with the emerging markets (South Korea is leading, occupying the $15^{\text {th }}$ place and being ahead of Russia for more than $1 / 4)$.

It should be noted that in recent years there has been a decline in interest of German businessmen to participate in investment projects in a number of sectors of the Russian economy. In 2013, the number of successful new investment projects with the participation of German investors was minimal. While Russian investors, by contrast, showed increasing interest in investment cooperation with German companies, as evidenced by a positive dynamics of FDI from Russia to Germany (Figure 2).

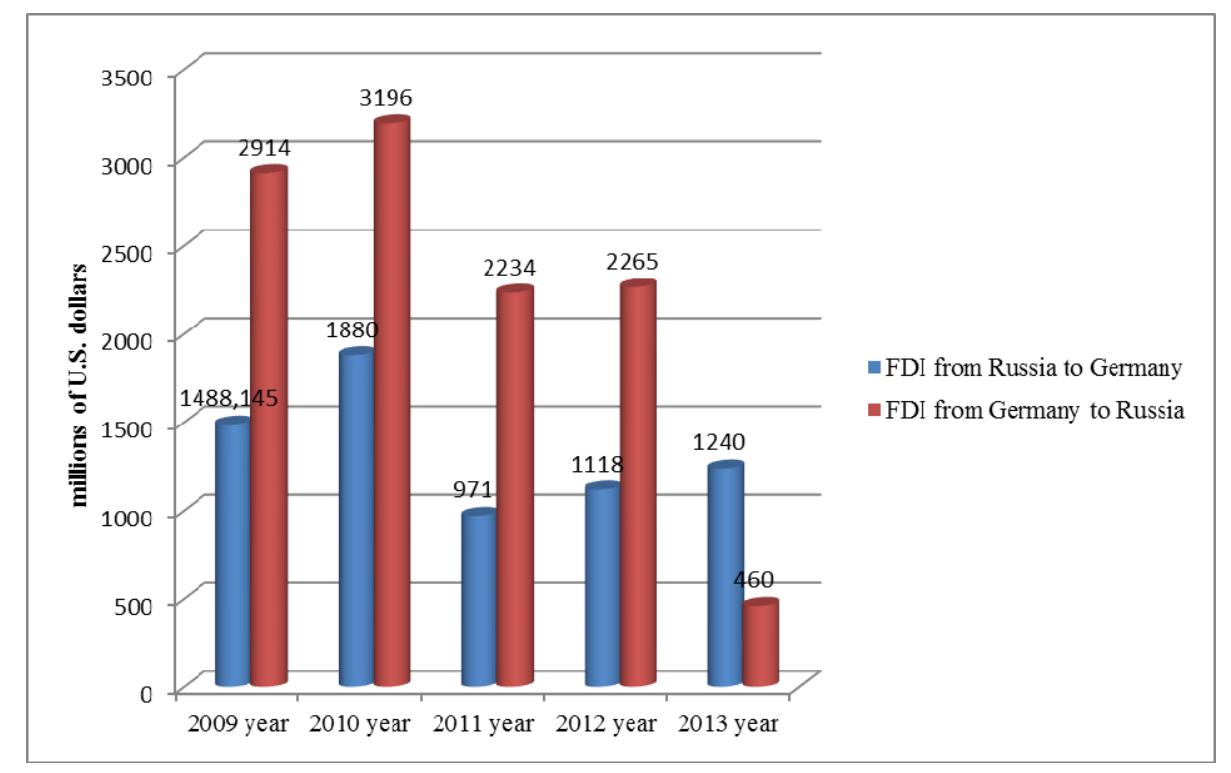

Figure 2. FDI dynamics between Germany and Russia for the period 2009-2013 
The global financial and economic crisis had a negative impact on FDI flows in both countries: for example, FDI from Germany to Russia decreased by $30.1 \%$, from Russia to Germany-almost half (48.4\%). At the same time, the lowest point in FDI in 2011 was passed and since 2012 the growth resumed. During 2013 there continued a cautious investment expansion of Russian companies in Germany. Along with the major projects there also existed small investment. Exactly they account for the bulk of the Russian capital, and many of them are not included in the German and Russian statistics

In general, the investments sphere, the value of Russia for Germany is markedly lower than in the trade sphere.

\section{Discussion}

According to the former German Defense Minister Volker Ruhe, in the future world there will be three centers of power: the United States, China and Europe, but Europe together with Russia. In other words, Europe, and with it, Germany will have a global impact only when they open their doors to Russia. This applies to both political and economic relations (Steininger, 2012).

At present, within the bilateral partnership of Germany and Russia there marked out the new tendencies: Russia becomes more attractive to Germany for further development of the new technologies and innovations. Cooperation between the two countries gradually acquires modernizing orientation. Therefore, a formulated in 2006 by Steinmeier F. V. regulation Annäherung durch Verflechtung (which is very close to the wording of Willy Brandt, in the early 70-ies of the past century-Wandel durch Annäherung). Having the aim of deepening cooperation between the EU and Russia, this principle for a while became defining in the architecture of the FRG's eastern policy. It was replaced by a new approach proposed by the same German politician-"Partnership for Modernization", officially fixed at the EU-Russia Summit in May 2010.

German-Russian trade and economic cooperation aimed at building sustainable economic development capable of ensuring the growth of key indicators in the post-crisis period.

Partnership between Russia and Germany contributes to the modernization of the country's economy through the development of Russia's import-substituting and in the future export-oriented production, the original basis for which is the import of German goods and the German capital; mutual investment for facilitating the development of promising technologies; the creation of new competitive products and services, promoting them on each other's markets, improving the business climate.

Modernizing alliance of the two countries over the past year confirmed the correctness of the made choice and has good prospects for the future, including those with regard to the debt problems of the Eurozone.

The new qualitative feature of the cooperation dynamics is to involve the sphere of innovation, which is a link between science and industry in the field of bilateral cooperation.

At the present stage of development Germany holds a leading position in the global market of high technology products (Germany-13.1\%, USA-12.8\%, Japan-9.2\%). Compared with the 90-ies years, when a world leader in the export of high-tech products were the U.S. companies (19 to 23) and then 17\%, Japan-10\%). In 2012, the trade surplus per capita in the segment of high-tech products in Germany amounted to 3904 U.S. dollars ("minus" 600 U.S. dollars-in the United States, 2356 U.S. dollars-in Japan). The positive tendencies in scientific and technological development of FRG include the growth of a positive surplus of trade balance in the segment of high-tech products. Thus, the increment rates in Germany for the period of 2004-2013 amounted to 44.7\%, which is 2.6 times higher than the increment rate in Japan. In the U.S. there still remained the trade deficit (Bank Restructuring in Practice, 2012).

Today, as part of further cooperation between Germany and Russia, there is present a political task of deepening cooperation in the area of innovation. Basic guidelines for further development and continuation of contacts in the sphere of innovations and high technologies include:

- Participation of the German partners in major Russian projects in the sphere of high technologies (such as Skolkovo) and vice versa;

- Strengthening the contact points between the scientific communities of Germany and Russia. To do this, almost all the major German research organizations have their offices in Russia. Such offices of major Russian scientific organizations are still not present in Germany;

- Increasing of Russian exports of services in software development for German customers.

The priority areas of geo-economic development of Russia and Germany may include strengthening industrial cooperation in the spheres of energy, engineering, aviation, transport, and pharmaceuticals (The Department). 


\subsection{Energy Sector}

Over the past decades, the interaction between Russia and Germany in the field of energy is constantly growing. It opened up new industries, new projects, and new horizons of cooperation.

In March 2013 in Moscow there was signed the "Road map for energy cooperation until 2050". Its strategic goal is "the formation of a pan-European energy space with a functioning integrated network infrastructure, open, transparent, efficient and competitive markets" (Road map, 2013), which will contribute to ensuring energy security and achieving sustainable development of the EU and Russia.

Today, cooperation between Russia and Germany in the energy sector has a strategic character. Throughout the recent period of economic cooperation between Russia and Europe, the deliveries of Russian gas and other primary energy resources to EU countries' markets remained a key segment of the trade turnover. These supplies are discussed as a base of the energy security of Europe for the past several decades.

Russian-German joint infrastructure projects, including the North and South Stream pipelines, work on energy security ensuring on the European continent. In turn, energy security means not only a reliable supply of energy consumers, but also free access to the markets of consumer providers. Market participants should be able to choose an acceptable for them cooperation variant-whether LNG or pipelines, purchase at spot prices or long-term contracts with reference to the petroleum product basket.

Exclusively the trade partnership in the energy sector has, for a number of reasons, the limited development potential. At the same time a significant potential for the development of cooperation between Russia and Germany is laid in energy engineering, advanced vocational training and human potential development of the workers occupied in the energy sector. This corresponds to the planned by Germany and Russia way of the innovation and economic development, and has good prospects, as it is reflected in the Road map of energy cooperation between Russia and the EU. One of the areas where it is already happening is the implementation of regional programs to improve the energy efficiency of municipal infrastructure, including heating system.

Significant potential also belongs to the application of advanced German technologies for the use of peat, which deposits are widespread in Russia, as well as enhanced cooperation in joint projects for infrastructure developing in the sectors of FEC and Transport in the territory of Germany and third countries.

\subsection{Engineering}

The Russian market is the first by the value for the German engineering industry in Eastern Europe and fourth in the world. Despite the global market upheavals, Germany maintains a leading position in the Russian market. It accounts for almost $25 \%$ of Russian imports of machinery and equipment.

Geo-economic partnership between Russia and Germany in the field of mechanical engineering is associated with the prospects of a number of joint projects of bilateral trade-economic and investment cooperation in the field of industry. Among them there is the construction of machine-tool building plant in Ulyanovsk region, the implementation of the "Volkswagen" company project in Kaluga, cooperation of the "Sinara" group and "Siemens" company in the field of transport engineering, the "Irkut" and "Airbus" companies-in the field of aircraft engineering. The promising areas of cooperation may include the priority areas of cooperation, such as technology transfer into the field of composite materials and machine tools.

\subsection{Aircraft Engineering}

Cooperative cooperation expanding into the aircraft engineering sphere for the medium and long term perspective is one of the attractive directions of the geo-economic development of Russia and Germany. For over twenty years, Russia has been a key partner for one of the largest German aircraft manufacturers Boeing in innovation, information technology, engineering capacity, space programs and procurement of titanium products. Back in 2009, Boeing and VSMPO-AVISMA, Russia's largest titanium producer opened a joint venture Ural Boeing Manufacturing in Upper Salda. UBM provides titanium forgings machining for the most technologically advanced aircrafts in the world 787-8 and -9 Dreamliner.

The promising cooperation projects may include the construction of the second Boeing plant SEZ "Titanium Valley". In November 2013, Boeing and State Corporation "Rosteh" signed a memorandum of mutual understanding on building a new plant of the joint venture UralBoeing Manufacturing (UBM), which is supposed to process titanium forgings for all aircraft of this air giant (Petersburg, 2014).

\subsection{Transport}

Cooperation between the Russian Federation and the Federal Republic of Germany is carried out in all areas of transportation, primarily in the field of railway transport. Key projects are worked out by the "Russian Railways", 
JSC with the major German companies. The major joint projects include the high-speed train "Sapsan"; high-speed train "Swallow" (Desiro RUS); development of a new generation locomotive-electric freight locomotive DC 2ES10 with asynchronous traction motors; production and delivery of new railcars of "RIC" dimensions.

Good opportunities for the introduction of advanced European innovation and further enhance of the technological partnership between Russia and Germany in the transport sector is associated with the development of the HSL Moscow-Kazan project (Mizin, 2014). Currently, 11 German companies participating in the German initiative for the development of high-speed lines (HSL) are ready to actively support the Russian Railways in an ambitious project to develop high-speed rail lines. In particular, the concern Siemens, a leader in electronics and electrical engineering supplied to Russia the first eight high-speed trains of "Sapsan" brand, thus initiating the high-speed railway transport in Russia.

The Deutsche Bahn Company, operator of the largest railway network in the center of Europe and international provider of global mobility and logistics, intends to transfer to Russia its know-how and to share more than 20 years of experience in the construction of HSL. Thus, Deutsche Bahn has developed a concept of security of railway stations and highways of Moscow-St. Petersburg, as well as participated in the development of a feasibility study for HSL Moscow-Kazan.

\subsection{Medicine and Pharmaceutics}

Pharmaceutical and medicine are also the priority areas for development of partnerships between Russia and Germany. Development of the new models of medical technology, pharmaceuticals and their mutual deliveries, new rehabilitation technologies, diagnosis and prevention of intractable diseases-all these is only a part of cooperation areas between the Russian Federation and Germany.

The Russian side is interested not only in increasing the volume of imported products from Germany, but primarily in the development of relevant industries in the Russian Federation with the participation of German investors, creation of joint ventures. Great importance will be devoted to the creation in Russian of the industry R \& D-centers and research laboratories with the help of German companies (The Russian-German, 2011).

\section{Conclusion}

Thus, the specified geo-economic development priorities in Russia and Germany are aimed at ensuring sustainable economic growth and overcoming the negative effects caused by the global crisis of the 2007-2009 years.

Throughout the entire period after the USSR collapse, Germany considered Russia as a key strategic partner in energy security ensuring and the main object of its "Eastern" policy.

Even the Germany's support for the policy of gradual sanctions against Russia in connection with the annexation of the Crimea, did not have a serious impact on the economic cooperation between the two countries in the priority areas of development. Germany's largest companies, including BASF SE, Siemens AG, Volkswagen AG, Adidas AG and Deutsche Bank AG, openly opposed the broad economic sanctions implemented against Russia. Many of the largest companies in Germany have a significant presence in Russia, in some cases being built by decades, and harsh economic sanctions will deprive them of market growth at a time when their domestic market-Europe-is stagnating.

According to analysts, Keele University, German growth could be reduced by as much as $2 \%$ if against Russia there will be implemented tougher sanctions (Pilskiy, 2014). In accordance with the current economic forecasts, it could plunge Europe's largest economy into recession and eventually even lead to another economic crisis.

Today, Russia has sufficient financial means to support a "sick" Eurozone. If the Russian Federation takes part in resolving the crisis of the Eurozone, mainly in the financial relation, its political influence in Europe will inevitably increase. Perhaps Russia now faces a unique historical opportunity of acquiring a decisive political influence in Europe by providing economic support to Eurozone.

The discussed in these article priorities give only some of the possibilities for the future development of geo-economic cooperation.

German business community has realized that, in the first place, it is responsible for the development of relations with Russia and the politicians do not own, as in the old days, an exclusive initiative of German-Russian relations. In this regard, the German economy should recognize its leading role and create the appropriate organizational structure. Russia, however, is to recognize that investors and the Russian economy itself need not only stability, but also more freedom and dynamics. In addition, Russia must realize its unique favorable 
economic situation and use it for political purposes.

\section{References}

Bank Restructuring in Practice. (2012). BIS Policy Paper, 6.

Belova, V. B. (2014). Germany (2013). Institute of Europe RAS, 11. Moscow.

Cecchini, P. (1988). Europa '92. Der Vorteil des Binnenmarktes. Baden-Baden.

Chernaya, I. P. (2012). Geo-economy (p. 32). Moscow.

German Council of Economic Experts. Federal Statistical Office of Germany. (n. d.). Against a backward-looking economic policy. Wiesbaden. Statistisches Bundesamt. Retrieved July 8, 2014, from http://www.sachverstaendigenrat-wirtschaft.de/fileadmin/dateiablage/gutachten/jg201314/JG13_Ges.pdf

Huntington, S. P. (1996). The Clash of Civilizations and the Remaking of World Order. Midgard: ACT.

Kennedy, P. (1987). The Rise and fall of the Great Powers: Economic Change and Military Conflict, from 1500 to 2000 (p. 439). New York: Random House.

Kozak, Y. G., Logvinov, N. S., \& Gribincha, A. I. (2013). International Economics: Questions and answers. Centre of educational literature, 64.

Mizin, N. (2014). Speed for export. Russian-German Chamber of Commerce Journal "Impulse", 24-25.

Panyshyn, O. A. (2014). Protectionism: The element of corrupt practices or progressive phenomenon? Competence, 3(114).

Parag, K. (2012). A New Era of Geo-economics: Assessing the Interplay of Economic and Political Risk. IISS Seminar, First session, 23-25 March. Understanding Geo-Economics and Strategy. Retrieved July 8, 2014 from http://www.iiss.org/-/media/Images/Events/conferences\%20from\%20import/seminars/papers/64321. pdf

Pilskiy, V. (2014). Business class for the Chancellor. Rossiyskaya Gazeta.

Road map of the energy cooperation until 2050. (2013). Portal about ESCO energy saving. Moscow. Retrieved July 8, 2014, from http://www.esco-ecosys.narod.ru/industry/2013_5/art130.pdf

Russian-German economic cooperation. (n. d.). Department of Foreign Affairs and work with business councils. Monthly Bulletin of Commerce and Industry of the Russian Federation "Foreign Economic Relations", 4. Retrieved July 8, 2014, from http://www.tpprf.ru/common/upload/13-05-Daydzhest_4.PDF

Russland 2013: Licht und schatten. (2013). Jahresbericht der Deutsch-Russischen Auslandshandelskammer. Der Bericht der Deutsch-Russischen Auslandshandelskammer (AHK). Retrieved July 8, 2014, from http://www.russland.ahk.de/fileadmin/ahk_russland/2014/Publikationen/Jahresbericht/JB13-web.pdf

Sanjaya, B. (2012). IISS Seminar, First session, 23-25 March. Understanding Geo-Economics and Strategy. Retrieved July 8, 2014, from http://www.iiss.org//media/Images/Events/conferences\%20from\%20import/ seminars/papers/64319.pdf

St. Petersburg International Economic Forum-2014 (SPIEF). (n. d.). Retrieved July 8, 2014, from http://www.forumspb.com/ru/2014/sections/35\#!

Statistics of the Russian-German trade cooperation. (n. d.). Official site of Commercial and Economic Office of the Embassy of Russian Federation in Germany. Retrieved July 8, 2014, from http://www.rfhwb.de

Steininger, A. (2012). Eurozone crisis and the energy crisis: The beginning of an amazing friendship? "International Cooperation"-topical application to the newspaper "The economy and life", 24.

The Department of European and American Ministry of Economic Development. Economic cooperation with the countries of Europe. (n. d.). Official portal of the Ministry of Economic Development. Retrieved July 8, 2014, from http://www.economy.gov.ru/minec/activity/sections/foreignEconomicActivity/cooperation/ economicEurope

The Russian-German cooperation in the field of medicine and pharmaceuticals is developing successfully. (2011). Economic and Trade Office of the Russian Federation in Germany. Retrieved July 8, 2014, from http://www.rfhwb.de/Docs/Sotr\%20v\%20med\%20i\%20farm.pdf

\section{Copyrights}

Copyright for this article is retained by the author(s), with first publication rights granted to the journal.

This is an open-access article distributed under the terms and conditions of the Creative Commons Attribution license (http://creativecommons.org/licenses/by/3.0/). 